\title{
How Severe Was the Credit Cycle in the New York-Northern New Jersey Region?
}

\author{
Jaison R. Abel and Richard Deitz
}

\begin{abstract}
U.S. households accumulated record-high levels of debt in the 2000s and then began a process of deleveraging following the Great Recession and financial crisis. However, the magnitude of these swings in the use of credit varied considerably within the United States. An analysis of trends in household debt over the past decade shows that compared with the nation as a whole, the New York-northern New Jersey region experienced a relatively mild "credit cycle," although pockets of financial stress exist.
\end{abstract}

\footnotetext{
he amount of debt taken on by U.S. households has increased rapidly over the last decade, reaching record-high levels. In today's dollars, the average household owed roughly $\$ 40,000$ in the mid-1980s, a figure that tripled to $\$ 120,000$ just before the Great Recession. With the onset of the recession and financial crisis, a contraction in credit availability accompanied by a weak economy created financial stress for many households. As a result, the U.S. household sector began a process of deleveraging, or reducing its debt. This increase and decline in the availability and use of credit—often referred to as a "credit cycle" — was more pronounced in some parts of the country than in others.
}

The severity of this credit cycle has important connections to the performance of regional economies. Higher debt supported a more robust housing market during the housing boom, creating spillovers into the broader economies of these areas and contributing to more rapid growth. Many of these trends began to reverse as the economy slowed and the financial crisis ensued. Indeed, during the Great Recession, areas with higher debt tended to have more severe downturns and, subsequently, weaker recoveries. ${ }^{1}$ In addition to providing important information about the economic health of households in a region, the nature and magnitude of local credit cycles help us better understand regional economic performance.

In this edition of Second District Highlights, we examine trends in household debt over the recent credit cycle for areas in the New York-northern New Jersey region. We use information from the Federal Reserve Bank of New York's Consumer Credit Panel to measure household debt for metropolitan areas in the region and across the country. Our analysis shows that differences in housing market dynamics within the region were associated with three varieties of credit cycles. First, in upstate New York, where the housing boom was muted, we find that household debt remained relatively low and increased far less than the national average did. Deleveraging since the financial

${ }^{1}$ See Mian and Sufi (2010 and 2011a). 
crisis has generally not been occurring, and loan delinquencies remain low compared with delinquencies nationwide. Second, in New York City, where the homeownership rate is much lower than the national rate because a large share of the population rents, we find that household debt remained at a lower level than that of the United States overall, although it did rise and fall in tandem with the nation's household debt; delinquencies remain high in the New York City area. Third, in Long Island and northern New Jersey, housing market dynamics closely paralleled the national average, and in these areas we find that household debt increased significantly and reached relatively high levels. Deleveraging in these regions has lagged the national pace somewhat, while delinquencies exceeded the national rate, suggesting that a higher share of households in these areas faced significant stress. We conclude that the effects of the recent credit cycle on the regional economy and the local business cycle have generally been less severe in the New York-northern New Jersey region than in the nation, although pockets of distress clearly exist.

\section{Household Debt, the Credit Cycle,}

and the Housing Market

The United States experienced a rapid increase in the availability and use of credit between 2001 and 2007, followed by a significant contraction that coincided with the onset of the financial crisis. As illustrated in Chart 1, the ratio of household debt to income rose at a fairly steady rate from 1960 through 2000, but increased sharply between 2000 and 2007. In just seven years, the household debt-to-income ratio rose by more that it had over the previous four decades. Balances increased on credit cards, auto loans, and student debt-but the largest contributor to this increase was housing-related debt.

Indeed, the vast majority of debt that households owe is associated with their homes. For the country as a whole, housingrelated debt (mortgages plus home equity lines of credit) in 2007 accounted for close to 80 percent of all debt, an increase from 70 percent in 2000. In fact, the total dollar value of mortgage debt more than doubled between 2000 and 2007, and the level of home equity debt rose roughly six-fold.

Because housing debt accounts for such a large share of all consumer debt, the dynamics of the housing market play a key role in shaping household debt patterns. Research has shown that an increase in credit availability in the early 2000s was linked to an increase in housing prices. ${ }^{2}$ Together, these empirical studies suggest that causality ran in both directions - an increase in available credit, especially mortgages, led to an increase in the demand for housing, and consequently prices. At the same time, a rise in housing prices led to an increase in borrowing. Homebuyers sought higher-balance mortgages to fund increasingly expensive homes; at the same time, existing homeowners tapped into their rising home equity by refinancing their mortgages or

\footnotetext{
${ }^{2}$ See, for example, Wheaton and Nechayev (2008), Mian and Sufi (2009), and Goetzmann, Peng, and Yen (2012).
}

Chart 1

\section{Ratio of Household Debt to Personal Income in the United States, 1960-2012}

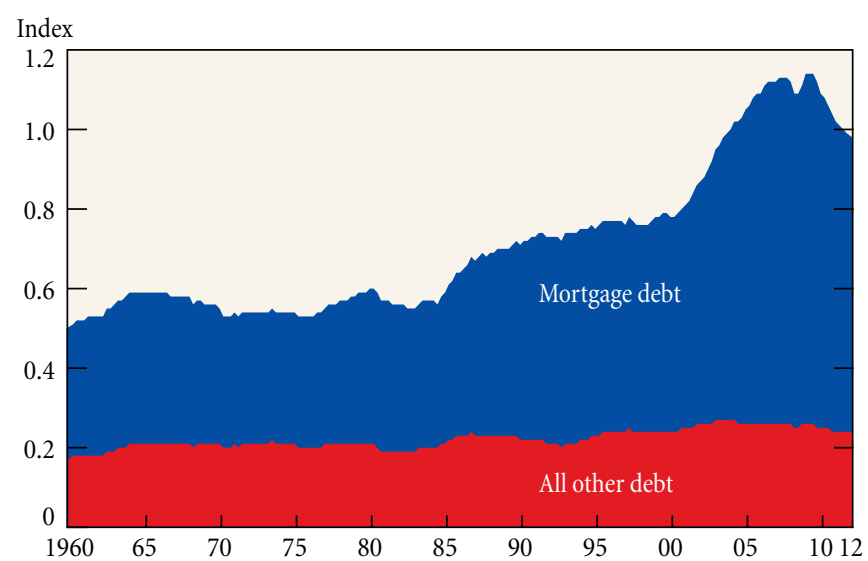

Sources: Federal Reserve Statistical Release Z.1, "Flow of Funds Accounts of the United States”; U.S. Bureau of Economic Analysis; Moody's Economy.com.

taking out home equity lines of credit. ${ }^{3}$ As the recession took hold and the financial crisis began, these trends reversed and debt began to decline.

The amplitude of local credit cycles largely reflected the degree to which local housing markets experienced a boom and bust. For example, in California, Florida, and Nevada - the states that experienced the biggest housing boom - household debt rose particularly rapidly and reached especially high levels before the recession; these states also experienced the most dramatic housing market declines, and households there have undergone a fairly significant degree of deleveraging.

While many parts of the country experienced a boom and bust in home sales and prices, this dynamic did not occur in many of the housing markets in the New York-northern New Jersey region. In upstate New York, home prices did not grow much during the housing boom and did not decline much (if at all) after the boom ended. ${ }^{4}$ As a result, one might also expect the local credit cycle to be less pronounced upstate. By contrast, home price dynamics were much closer to the national average for downstate New York and northern New Jersey; consequently, all else equal, one might expect the increase and decrease in household debt in these places to more closely follow the national pattern. New York City's housing market has a particularly unique dynamic - a significant percentage of households in the area rent and thus carry no mortgage debt. This suggests that the level of debt would be lower for households in the area. We now examine in detail the nature of the credit cycle in the New York-northern New Jersey region.

\footnotetext{
${ }^{3}$ See Mian and Sufi (2011b).

${ }^{4}$ See Abel and Deitz (2010).
} 


\section{The Increase in Household Indebtedness}

To analyze regional trends in household debt, we rely on the Federal Reserve Bank of New York's Consumer Credit Panel, which contains data on household borrowing activity. ${ }^{5}$ The data are quarterly and begin in 1999, allowing for analysis of more than a decade of information. Data are compiled based on a representative sample of individuals with a credit report and include information on all of an individual's debt obligations, including credit cards, student loans, auto loans, home equity lines of credit, and mortgages. While little demographic information about the individuals is available, the data do provide some information about their geographic location, which we use to construct regional measures of household debt over time. To measure differences in household indebtedness across areas, we begin by looking at regional patterns in debt-to-income ratios. Because incomes vary considerably across areas, one might expect the amount of debt that individuals can accommodate to differ from one place to another. Thus, to obtain a measure of the debt burden that is comparable across areas, we divide a location's total debt by total income to yield a region's debt-to-income ratio. ${ }^{6}$

Chart 2 shows the debt-to-income ratio for selected metropolitan areas compared with the United States as a whole. The national debt-to-income ratio peaked at a level of around 1 , meaning that a person's annual income was roughly equal to the amount of his total debt. For example, a person with an average income of $\$ 40,000$ per year would have about $\$ 40,000$ in total debt. ${ }^{7}$ For the nation as a whole, the debt-to-income ratio increased until around the time the recession began, then held fairly steady at a value of around 1 until 2009, when it began to decline modestly.

In some places, household indebtedness grew much more rapidly than average and reached levels above that of the nation. This was especially true in states where the housing boom was strongest. For example, in Las Vegas, Nevada, the debt-to-income ratio doubled from around 0.8 in 1999 to more than 1.6 in 2009. The rising household debt burden was even more pronounced in places like Riverside, California, where the ratio rose from around 0.9 in 1999 to a little more than 2.0 in 2009 , more than doubling in just ten years. Increases of this magnitude were common in places that experienced a strong housing boom, where home prices rose rapidly and mortgage balances increased sharply in tandem.

These increases in household debt burdens were much different in many parts of New York and northern New Jersey. The debt

\footnotetext{
${ }^{5}$ Lee and van der Klaauw (2010) provide more details on the Consumer Credit Panel.

${ }^{6}$ While the debt-to-income ratio allows for a more uniform comparison of debt burdens across regions, it is important to note that this measure does not account for differences in demographics, such as age or education, or the presence of other sources of wealth that may contribute to differences in the amount of outstanding debt observed across locations.

${ }^{7}$ In the case of debt held jointly by a couple — for example, a mortgage — the debt balance is split evenly between the two individuals.
}

Chart 2

\section{Ratio of Household Debt to Personal Income} for Selected Metropolitan Areas, 1999-2011

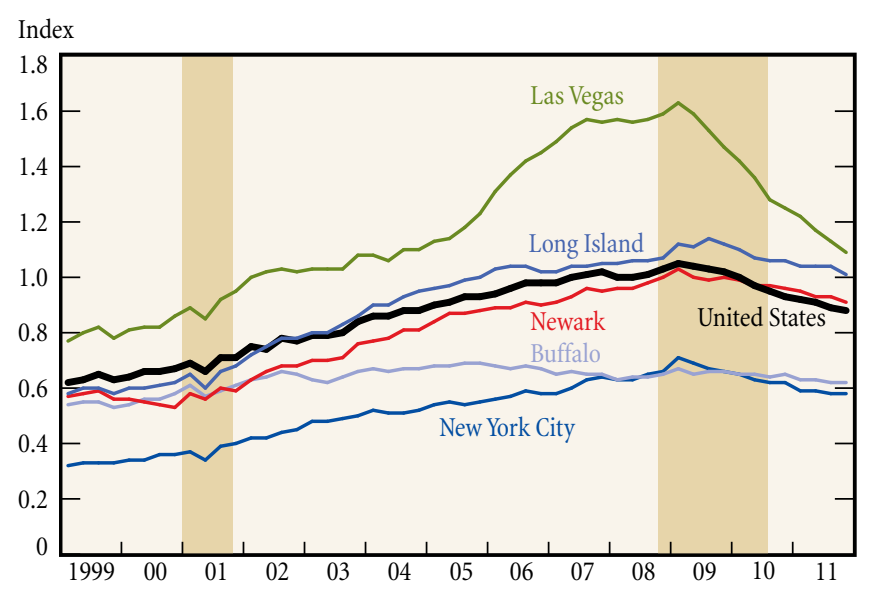

Sources: FRBNY Consumer Credit Panel/Equifax; Bureau of Economic Analysis; Moody's Economy.com.

Notes: New York City includes only the five boroughs of Manhattan, the Bronx, Brooklyn, Queens, and Staten Island. The shaded areas indicate periods designated national recessions by the National Bureau of Economic Research.

burden held well below average in Buffalo, for example, reaching a peak of just 0.7 and increasing at a much more modest pace than that of the nation. In large part, this trend reflects the fact that home prices did not rise much during the housing boom. The debt-to-income ratio in New York City also held well below that of the nation, likely influenced by the high share of renters. The pace of increase in the city's debt burden, however, mirrored that of the nation: the two trend lines in Chart 2 are roughly parallel. In Long Island and parts of northern New Jersey, debt levels were similar to the national level in the early 2000s; but they increased somewhat more sharply than the national level did, resulting in above-average debt burdens following the recession.

A more comprehensive view of debt burdens across the country is shown in Exhibit 1. Here, we plot the debt-to-income ratio for all metropolitan areas during third-quarter 2008, when aggregate debt in the United States reached its peak. Metro areas in blue have debt-to-income ratios below the ratio for the nation, while those in red have ratios above it. A clear geographic pattern emerges, one that is closely tied to the geography of the housing boom. The highest levels of debt tended to appear in places that had the steepest home price appreciation; the lowest were in places where home prices did not climb as much. ${ }^{8}$ The highest debt burdens appear in California, Oregon, Washington, Nevada, Arizona, and Florida, as well as in a few spots along the Washington, D.C.-Boston corridor. The ratios tended to be relatively low across much of the center of the country and along the Great Lakes. There are some exceptions in Michigan and Illinois,

\footnotetext{
${ }^{8}$ Abel and Deitz (2010) provide more detail on the geography of the most recent U.S. housing cycle.
} 
Exhibit 1

\section{Debt-to-Income Ratios across U.S. Metropolitan Areas, Third-Quarter 2008}

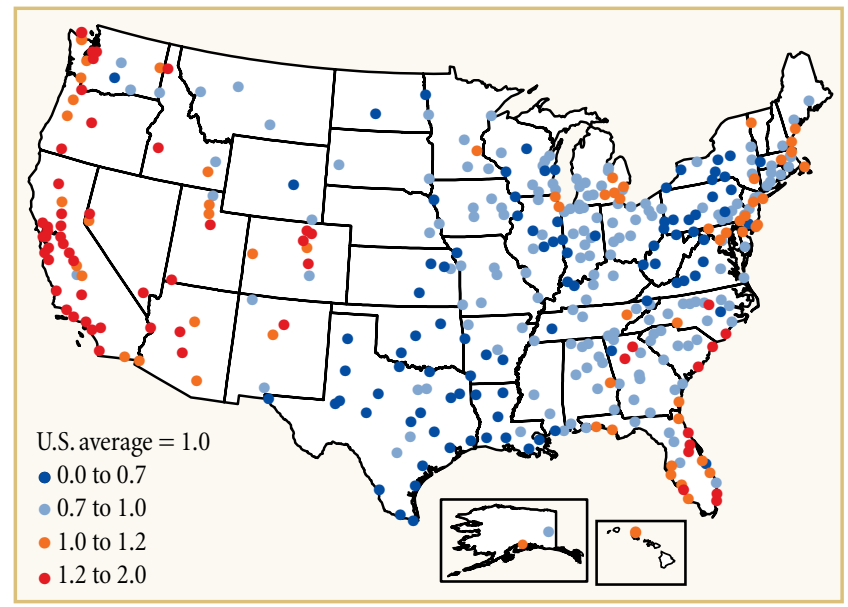

Sources: FRBNY Consumer Credit Panel/Equifax; Bureau of Economic Analysis; Moody's Economy.com.

where debt burdens were relatively high, reflecting both relatively sharp income declines during the recession and high levels of debt.

\section{Deleveraging after the Great Recession and Financial Crisis}

Household finances came under increasing pressure during the Great Recession and financial crisis that followed. As a result, household debt began to decline. Two economic forces were especially important contributors to this decline. First, adverse economic circumstances-especially rising unemploymentlikely made it more difficult for affected households to pay their debt obligations, contributing to an increase in defaults. To the extent that debt balances were reduced through this mechanism, losses were absorbed by lenders. Second, household saving patterns clearly changed. The saving rate for households was just 1.6 percent in 2005, but it climbed to 5.3 percent in 2010. This increase suggests that at least some consumers began to pay down their debt balances. Indeed, recent research finds that both defaults and debt repayment have been responsible for declining debt balances. ${ }^{9}$ Thus, deleveraging is a process that has been shared by both borrowers and lenders.

Like the increase in household debt burdens in the early 2000s, the decline in debt burdens differed across the country (Chart 2). For the United States as a whole, the debt-to-income ratio declined about 16 percent, from 1.05 at its peak to about 0.88 by year-end 2011. In some places, such as Las Vegas, the ratio declined much more substantially, while in others the decline was more muted. Chart 3 presents the debt-to-income ratio for metropolitan areas in the region at each area's peak and the ratio at the end of 2011. The distance between the bars on the chart indicates the extent of the decline in local debt burdens.

\footnotetext{
${ }^{9}$ See Brown et al. (2010).
}

Chart 3

Debt-to-Income Ratios for Selected Metropolitan Areas: Local Peak and Fourth-Quarter 2011

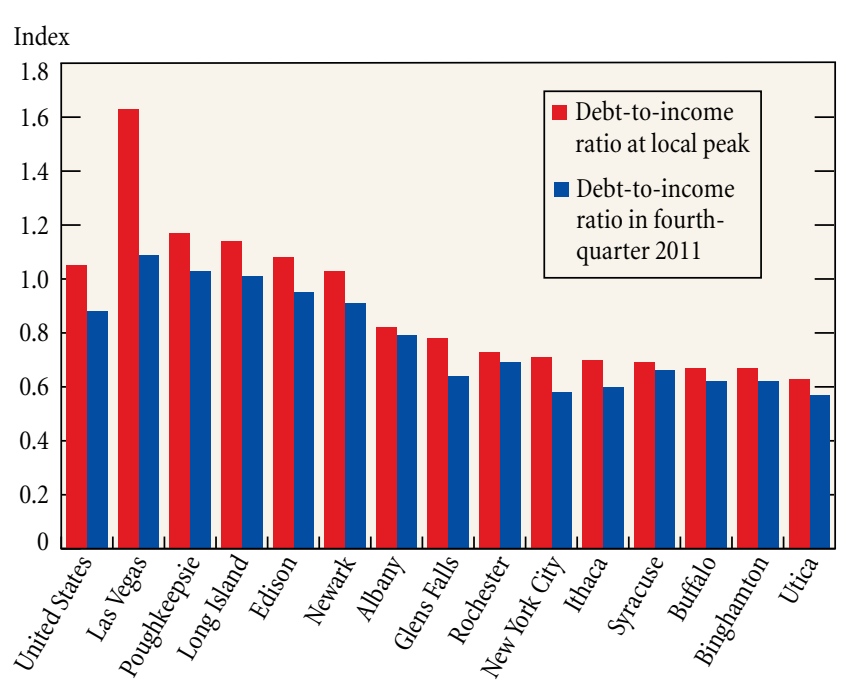

Sources: FRBNY Consumer Credit Panel/Equifax; Bureau of Economic Analysis; Moody's Economy.com.

Note: New York City includes only the five boroughs of Manhattan, the Bronx, Brooklyn, Queens, and Staten Island.

Across the region, the decline in debt-to-income ratios has been generally small, although in Poughkeepsie, Glens Falls, New York City, Long Island, Edison, and Newark, the declines were on par with the national decline.

While debt burdens have fallen across the region, some of the decline in debt-to-income ratios after the recession ended may reflect stronger income growth, rather than declines in the amount of debt households owe. To examine the amount by which households are reducing their debt levels independent of variations in income, we compare the dollar amount of debt owed by the average individual between the national peak in third-quarter 2008 and the fourth quarter of 2011. Chart 4 shows the average change in debt on a per capita basis for the nation as well as for the region. During this period, the average person in the United States saw debt decline by a little more than $\$ 5,000$. The majority of this decline was in housing-related debt. Las Vegas provides an example of particularly significant deleveraging. There, the average person's debt declined by more than $\$ 27,000$ over this period, with an especially sharp decline occurring in average mortgage debt. It is likely that since home prices fell precipitously in Las Vegas, defaults played a key role in reducing mortgage debt. With nearly three-quarters of all mortgaged properties in Las Vegas "underwater" in 2010 — that is, the mortgage balance exceeded the property's value-defaults were not uncommon. In fact, by the end of 2011, the home foreclosure rate of 11 percent in Las Vegas was double the average across U.S. metro areas. ${ }^{10}$

\footnotetext{
10 For details, see http://www.foreclosure-response.org/maps_and_data/ metro_delinquency_data_tables.html\#sub2.
} 
Chart 4

Change in Debt Per Capita between Third-Quarter 2008 and Fourth-Quarter 2011 for Selected Metropolitan Areas

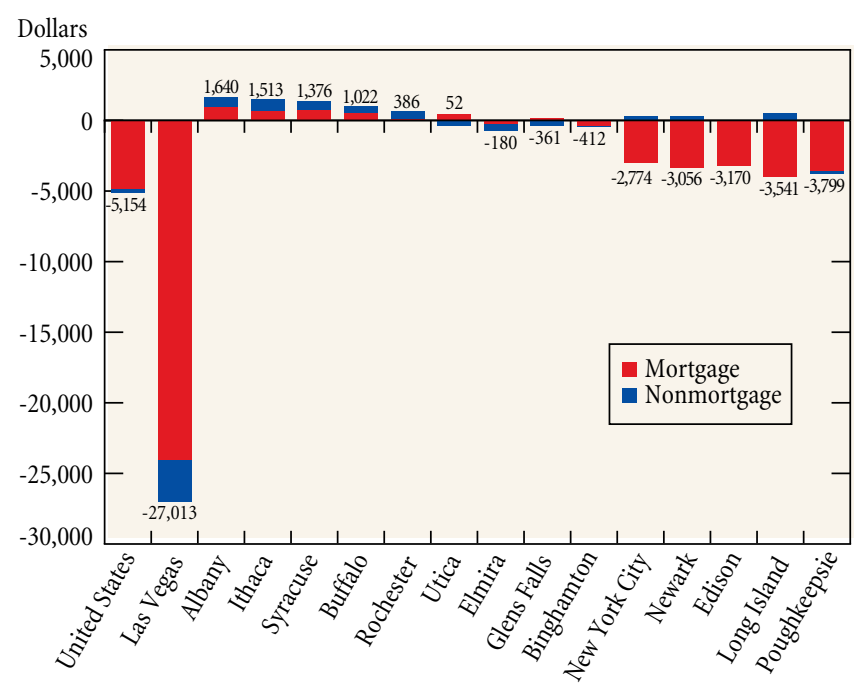

Source: FRBNY Consumer Credit Panel/Equifax.

Note: New York City includes only the five boroughs of Manhattan, the Bronx, Brooklyn, Queens, and Staten Island.

Throughout much of upstate New York, deleveraging has not only been less significant-it has, in fact, not been occurring. Debt levels climbed somewhat higher on average in Albany, Ithaca, Syracuse, Buffalo, Rochester, and Utica, with increases in mortgage debt in each of these metro areas. The impetus for deleveraging in upstate New York has so far been relatively low, since debt levels rose at a modest pace and did not climb to particularly high levels. Further, since home prices have been fairly stable in upstate New York in recent years, fewer mortgages are underwater. Despite these small increases, debt levels have been declining in Poughkeepsie, New York City, Long Island, Edison, and Newark, although the dollar value of these declines is well below the national average.

While certainly significant, deleveraging across New York and northern New Jersey has been less severe than in the nation. However, this does not necessarily imply that households in the region are, by and large, in a favorable financial position. Debt levels remain high relative to where they were before the housing boom, and many households may be struggling. We now examine measures of loan delinquency to assess the severity and scope of local households' financial stress.

\section{How Severe Is Financial Stress in the Region?}

As the effects of the recession took hold and the financial crisis unfolded, the unemployment rate increased significantly, and income for many households declined. At the same time, home prices began to fall sharply in much of the country, reducing the value of this critical asset for many households. To what degree
Chart 5

Share of Total Debt Ninety or More Days Delinquent in the United States and in the New YorkNorthern New Jersey Region, 2005-12

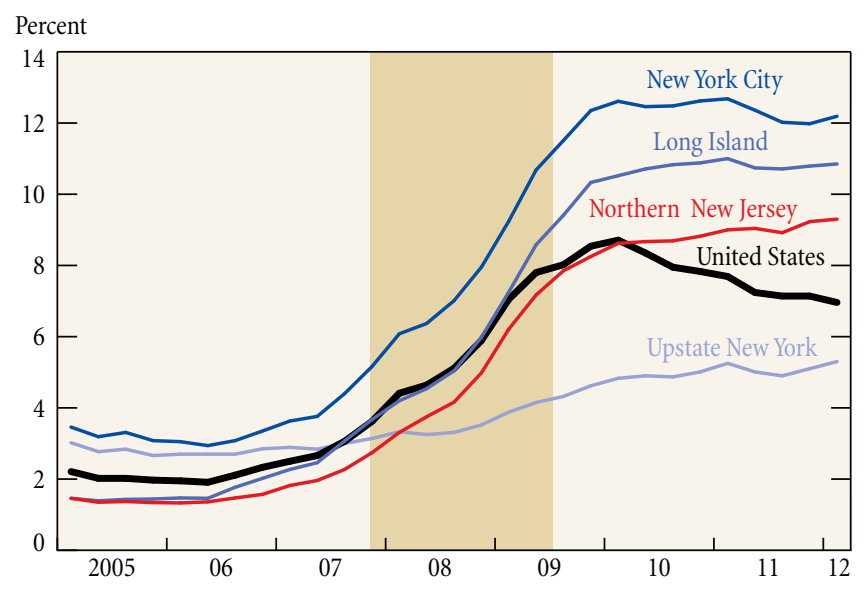

Source: FRBNY Consumer Credit Panel/Equifax.

Notes: New York City includes only the five boroughs of Manhattan, the Bronx, Brooklyn, Queens, and Staten Island. The shaded area indicates a period designated a national recession by the National Bureau of Economic Research.

were household finances stressed by these trends? To answer this question, we examine the share of household debt that has become delinquent.

We measure the delinquency rate as the percentage of loan balances ninety days or more overdue and, together with the national rate, plot these figures for four regional aggregates: upstate New York, New York City, Long Island, and northern New Jersey (Chart 5). For the nation as a whole, the delinquency rate rose from around 2.0 percent to a high of 8.7 percent in early 2010 . The increase in the delinquency rate reflects a combination of more households becoming delinquent for the first time and greater amounts of debt becoming delinquent. Since 2010, the national delinquency rate has declined steadily, and was a little less than 7 percent during first-quarter 2012. This decline suggests that the level of financial stress may be edging lower, in part because households are deleveraging.

The pattern of delinquency in the region differs from the national pattern in a number of ways. In upstate New York, the delinquency rate was slightly above average before the recession and rose slowly and steadily over time, holding well below the national rate once the recession began. Although upstate's rate, unlike the national rate, has continued to rise over the past couple of years, it is still below the national rate, suggesting that while household finances have become more stressed over time, such stress is not as pronounced as it is nationwide. In New York City, the delinquency rate tended to be higher than average, and it increased more sharply than the U.S. rate did during the recession. It climbed to a peak of 12.7 percent in 2011 and has fallen very 


\section{Exhibit 2}

\section{Share of Total Debt Ninety or More Days Delinquent in the New York-Northern New Jersey Region, First Quarter 2012}

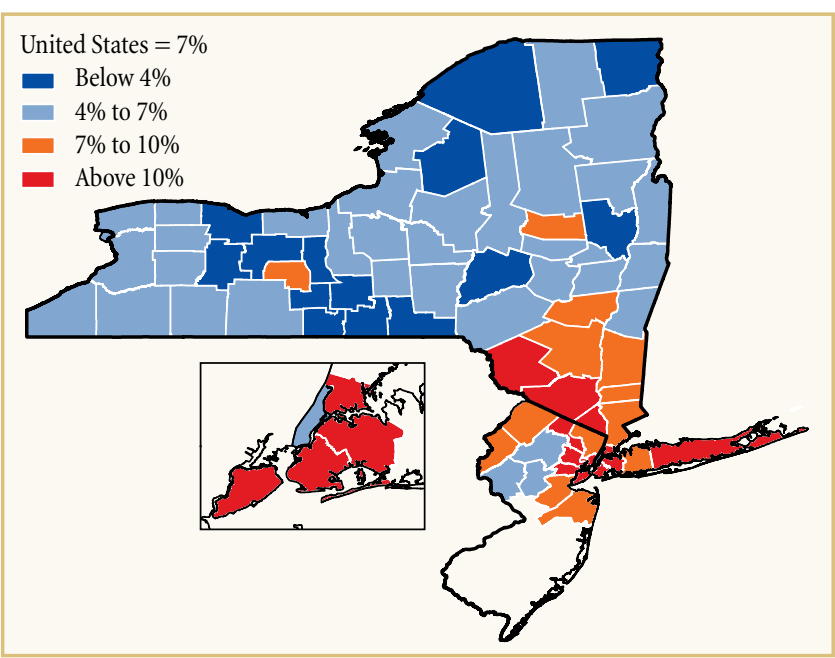

Source: FRBNY Consumer Credit Panel/Equifax.

little since. This pattern suggests a relatively high level of financial stress in New York City. In Long Island, the rate also rose sharply, reaching 11 percent, and like New York City's rate, it has not fallen. Similarly, in northern New Jersey, the rate has continued to climb, and it has held above the national rate since $2010 .{ }^{11}$

More geographic detail on delinquency rates across the New York-northern New Jersey region is provided in Exhibit 2, which plots the rate by county during first-quarter 2012. The vast majority of counties in upstate New York have delinquency rates well below the national rate. However, delinquency rates are above average in downstate New York, with particularly high rates in Sullivan, Orange, and Rockland Counties. In and around New York City, delinquency rates are quite elevated in the Bronx, Queens, and Brooklyn, as well as in parts of Long Island, while Manhattan's rate is well below average. Rates are also high across most counties in northern New Jersey. Thus, pockets of especially high household financial stress are apparent in the New Yorknorthern New Jersey region.

\section{Conclusion}

Households accumulated a substantial amount of debt in the United States during the 2000s, then began a process of deleveraging as a result of the Great Recession and financial crisis. However, there were significant differences in the magnitude of

\footnotetext{
${ }^{11}$ New York City's above-average delinquency rate in part reflects the fact that a lower share of its household debt is tied to mortgages, which tend to have lower delinquency rates than other forms of debt. Moreover, New York and New Jersey both have a relatively lengthy foreclosure process, which may be contributing to the region's rising delinquency rates, especially when compared with states where the foreclosure process is shorter.
}

this credit cycle across the country. Households in areas where the housing boom was concentrated generally amassed relatively high levels of debt and then engaged in a fairly significant degree of deleveraging, especially when compared with households where the housing boom and bust were less acute. Our analysis shows that debt levels have been low in much of the New York Statenorthern New Jersey region compared with the United States overall, although debt burdens rose to high levels in some areas in the region. As a result, the deleveraging process, while significant, has been less pronounced in New York and northern New Jersey than in other parts of the country.

Regional credit cycles have had important effects on local economies. When borrowing increased significantly in some parts of the country, it supported consumer spending in those places. But as consumer finances deteriorated during the recession, the trend was reversed, and it likely contributed to a dampening of spending in such high-debt locations. Indeed, research has found a link between patterns of household leverage and local economic performance. In particular, areas that accumulated the largest household debt burdens experienced a more severe downturn during the Great Recession. ${ }^{12}$ Moreover, as the U.S. economy recovered, places with high household debt burdens had weaker job performance and less robust growth in residential investment and durable goods consumption than those with low household debt burdens. ${ }^{13}$

These findings help explain why much of the New Yorknorthern New Jersey region has outperformed the nation during and since the Great Recession. Looking ahead, we suggest that the relatively low debt burden in upstate New York and New York City means that households there will generally have less need to improve their finances than households in other parts of the country. Accordingly, there may be less of a drag on regional economic performance in the future. However, debt burdens are higher and relatively close to the national average in Long Island and northern New Jersey, where economic performance has been below average during the recovery. Indeed, pockets of financial stress clearly remain in the region, as evidenced by relatively high and rising delinquency rates in much of downstate New York and northern New Jersey.

\section{References}

Abel, Jaison R., and Richard Deitz. 2010. "Bypassing the Bust: The Stability of Upstate New York's Housing Markets during the Recession." Federal Reserve Bank of New York Current Issues in Economics and Finance 16, no. 3 (March).

Brown, Meta, Andrew Haughwout, Donghoon Lee, and Wilbert van der Klaauw. 2010. "The Financial Crisis at the Kitchen Table: Trends in Household Debt and Credit." Federal Reserve Bank of New York Staff Reports, no. 480, December.

Goetzmann, William N., Liang Peng, and Jacqueline Yen. 2012. “The Subprime Crisis and House Price Appreciation." Journal of Real Estate Finance and Economics 44, no. 1 (January): 36-66.

\footnotetext{
${ }^{12}$ See Mian and Sufi (2010).

${ }^{13}$ See Mian and Sufi (2011a).
} 
Lee, Donghoon, and Wilbert van der Klaauw. 2010. "An Introduction to the FRBNY Consumer Credit Panel.” Federal Reserve Bank of New York Staff Reports, no. 479 , November.

Mian, Atif, and Amir Sufi. 2009. “The Consequences of Mortgage Credit Expansion: Evidence from the U.S. Mortgage Default Crisis." Quarterly Journal of Economics 124, no. 4 (November): 1449-96.

.2010. "Household Leverage and the Recession of 2007 to 2009." IMF

Economic Review 58, no. 1 (August): 74-117. .2011a. "Consumers and the Economy, Part II: Household Debt and the Weak U.S. Recovery." Federal Reserve Bank of San Francisco Economic Letter, no. 2011-02, January.

.2011b. "House Prices, Home Equity-Based Borrowing, and the U.S.

Household Leverage Crisis.” American Economic Review 101, no. 5 (August): 2132-56.

Wheaton, William C., and Gleb Nechayev. 2008. “The 1998-2005 Housing 'Bubble' and the Current 'Correction': What's Different This Time?” Journal of Real Estate Research 30, no. 1: 1-26.

\section{Follow Us on Twitter!}

The Research Group recently launched a Twitter feed, designed to offer the first word on developments in the Group, such as:

- new publications and blog posts,

- updates on economists' work and speaking engagements,

- postings of key indexes and data,

- media coverage of the Group's work, and

- other news of interest to website visitors.

\section{Follow us: @NYFedResearch}

\section{ABOUT THE AUTHORS}

Jaison R. Abel is a senior economist and Richard Deitz an assistant vice president in the Research and Statistics Group of the Federal Reserve Bank of New York.

Current Issues in Economics and Finance is published by the Research and Statistics Group of the Federal Reserve Bank of New York. Linda Goldberg and Thomas Klitgaard are the editors.

Editorial Staff: Valerie LaPorte, Mike De Mott, Michelle Bailer, Karen Carter, Anna Snider

Production: Jessica lannuzzi, David Rosenberg, Jane Urry

Subscriptions to Current Issues are free. Send an e-mail to Research.Publications@ny.frb.org or write to the Publications Function, Federal Reserve Bank of New York, 33 Liberty Street, New York, N.Y. 10045-0001. Back issues of Current Issues are available at http://www.newyorkfed.org/research/current_issues/.

The views expressed in this article are those of the authors and do not necessarily reflect the position of the Federal Reserve Bank of New York or the Federal Reserve System.

Follow us on Twitter:@NYFedResearch 